International Journal of

Health, Medicine and

Nursing Practice

(IJHMNP)

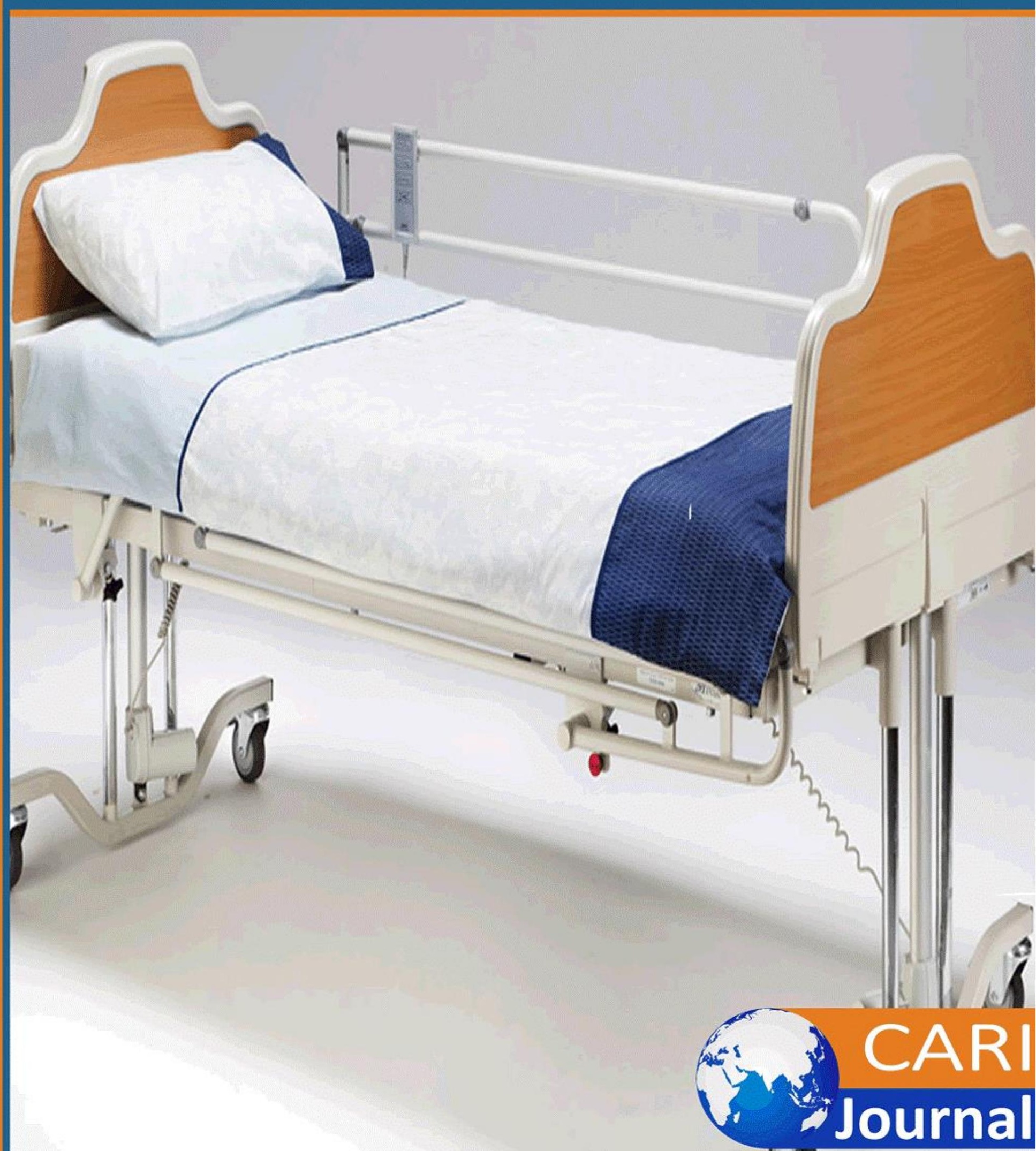




\title{
PERCEPTION OF NURSING STAFF TOWARD THE APPLICATION OF PROFESSIONAL NURSING CARE MODEL (MAKP) AND JOB SATISFACTION IN GOVERNMENT HOSPITALS LAHORE
}

\author{
${ }^{1 *}$ Saba shahid \\ The university of lahore, Pakistan. \\ *Corresponding Author: Saba shahid_Email: Saba.shahid610@gmail.com \\ ${ }^{2}$ Muhammad Afzal \\ The university of lahore, Pakistan. \\ ${ }^{3}$ Kousar parveen \\ The university of lahore, Pakistan.
}

Purpose: Nursing care delivery is a provision of nursing care in the hospital because the nurse has 24-hour interaction with the patient. PROFESSIONAL NURSING CARE MODEL or in Indonesian language is (MAKP). The aim of this study is to evaluate the perception of nursing staff toward the application of professional nursing care model and job satisfaction. Evaluate the nurses' perception toward the implication of nursing care model (MAKP) and job satisfaction.

Methodology: A cross sectional study was conducted in government hospital of Pakistan from February 2021 to April 2021. Sample size was 134 and sampling was conducted via simple random sampling by distributing questionnaire. Data was analyze by using the SPSS version 21.

Findings: All the participants are female. It was revealed that the nurses have sufficient knowledge about the 5 components of MAKP model and there is no relation between application of nursing care model (MAKP) with job satisfaction.

Unique Contribution to Theory, Practice and Policy: The nurses have sufficient knowledge about the 5 component of professional nursing care model and the job satisfaction has no association with the application of nursing care model except of delegation, co-ordination and leader.

Key words. Perception, MAKP model, Job satisfaction

\section{INTRODUCTION}

Since the nursing service lasts 24 hours and the nurse is one of the most dominant health staff in the hospital, nursing service provision reflects the quality of care provided. The chosen nursing care model should be able to boost nurses' efficiency rather than add to their workload, and should aim to make service delivery easier [1]. According to previous systematic studies, using primary nursing care guidelines will enhance nursing service and nurse autonomy while having no effect on job satisfaction [2]. Professional Nursing Care Model, or MAKP in Bahasa Indonesia, is a type of nursing care that is being established in Indonesia. Over 14,465,439 nurses work around the world. About 3 million nurses work in the United States, with 2.7 million of them working. Leadership, coordination, communication, delegation, and supervision are the five dimensions of MAKP implementation [3]. These factors serve as 
measures of how well nursing care is implemented. MAKP has been introduced in a variety of hospitals. An analysis of the hospital's MAKP implementation revealed that aspects of promotion, supervision, teamwork, and working conditions had an effect on nurse job satisfaction [4]. Furthermore, personal correspondence with ten nursing staff revealed that no instruction on the application of MAKP had ever been given. Low job satisfaction is a major factor associated with nurses leaving their current employment and the profession, and it is a global issue because of the possible effect on the quality and safety of patient care[5]. Job satisfaction is the most promising dimension on which healthcare organizations should act to reduce hospital turnover intention among nurses. Overall, our findings suggest developing selfefficacy, work engagement and agentic capacities to improve nurses' job satisfaction. The aim of this study is to find out how nurses feel about MAKP to see if it has anything to do with job satisfaction.

\section{METHODOLOGY}

A cross sectional survey was conducted at government hospital of Lahore Pakistan. The demographic includes (Age, Gender, Eucation, Duration of work, Status). The research independent variable is (professional nursing care model) and dependant variable is job satisfaction. This survey was conducted by the nurses working in in patient department. The research included 92 nurses who were granted the authority and were assigned to provide nursing care directly to patients. During the months of February and april 2021, the researcher conducted interviews with participants using standardised questionnaires. Nurse characteristics (age, gender, education, length of service, and employment status) were collected, as well as nurses' opinions of MAKP implementation and work satisfaction. The nurses' impressions toward MAKP model is evaluated by the five aspects, leadership, communication, delegation, supervision and supervision [6]. Likert scale was used, The total score for each factor is 20, with a score 1 representing "disagree." of 2 for 'less agree,' 3 for 'agree,' and 4 for 'strongly agree. With the aid of a full consent form and a consent letter attached to the questionnaire, participants were given adequate details about the study. Participants' confidentiality was taken into account when they were told. The supervisory aspect was assessed in terms of the supervisor's position, schedule, and form of supervision. The coordination dimension was assessed in terms of internal team coordination, as well as coordination with similar units and other health teams. The skill and authority of the representation element, as well as the equality and promptness of the task, were evaluated. The aspects of performance, role models, transformational leadership, and incentives were used to assess the leadership element. The form, mechanism, technique, and communication barrier aspects of communication were all assessed. This survey also used a Likert scale for the same categories as the previous one, resulting in a total score of 100 . If the score was 75 , respondents were classified as happy, and if the score was 75, they were classified as unsatisfied. The data were analyzed by using SPSS version 21. The Chi square test is used to measure the perception of MAKP model and job satisfaction. Data was coded, captured on Excel, and then imported into the statistical Package for Social Sciences (SPSS) version 21.0 for descriptive analysis and statistics after data collection was completed. 


\section{RESULTS}

The knowledge was obtained from female nurses. Since male nurses are in short supply. The majority of nursing staff, as seen in Table 1, is over the age of 20-29 years (65.9\%) and were female. Most of the respondents had diplomas (89.9\%), staff nurses with degree are $(10.1 \%)$ with duration of working $>12$ years $(63.8 \%)$ and were civil servants.

The table 2 shows the nurses perception is positive toward the professional nursing care model with the indication of A(agree), DA (disagree), SA (strongly agree). SD (strongly disagree), LA (less agree). The perception toward leadership is (66.7\%), perception toward communication is $(61.6 \%)$, perception toward co-ordination is $(63.8 \%)$, perception toward delegation is $(60.1 \%)$, perception of supervision is $(54.3 \%)$. The association between nursing care model and job satisfaction is measured by applying regression test. The results are shown in table 03 .

For the purpose of testing the stated the relationship, inferential statistics of Regression analysis was used.

Table 01: Characteristics of Respondents

\begin{tabular}{|c|c|c|c|c|c|}
\hline \multirow{2}{*}{$\begin{array}{l}\text { Characteristics } \\
\text { Age }\end{array}$} & \multicolumn{3}{|l|}{ f } & \multicolumn{2}{|l|}{$\%$} \\
\hline & & & & & \\
\hline $20-29$ & \multicolumn{3}{|l|}{79} & \multicolumn{2}{|l|}{65.9} \\
\hline $30-39$ & \multicolumn{3}{|l|}{41} & \multicolumn{2}{|l|}{31.2} \\
\hline$>40$ & \multicolumn{3}{|l|}{4} & \multicolumn{2}{|l|}{2.9} \\
\hline \multicolumn{6}{|l|}{ Gender } \\
\hline & \multicolumn{3}{|l|}{138} & \multicolumn{2}{|l|}{100} \\
\hline \multicolumn{6}{|l|}{ Male } \\
\hline \multicolumn{6}{|l|}{ Education } \\
\hline Nursing degree & \multicolumn{3}{|l|}{14} & \multicolumn{2}{|l|}{10.1} \\
\hline Nursing diploma & \multicolumn{3}{|l|}{110} & \multicolumn{2}{|l|}{89.9} \\
\hline \multicolumn{6}{|l|}{ Duration } \\
\hline$>12$ year & \multicolumn{3}{|l|}{77} & \multicolumn{2}{|l|}{63.8} \\
\hline$<12$ year & \multicolumn{3}{|l|}{47} & \multicolumn{2}{|l|}{36.2} \\
\hline \multicolumn{6}{|l|}{ Status } \\
\hline Civil servant & \multicolumn{3}{|l|}{138} & \multicolumn{2}{|l|}{100} \\
\hline \multicolumn{6}{|l|}{ Table 02: Perception of leadership } \\
\hline Perception of leadership & $66.7 \%$ & 7.2 & 2 & 1.4 & 24.6 \\
\hline PERCEPTION OF COMMUNICATION & $61.6 \%$ & 5.1 & 8 & 7 & 19.5 \\
\hline PERCEPTION OF DELEGATION & $60.1 \%$ & 5.8 & 8.7 & 3 & 24 \\
\hline PERCEPTION OF CO-ORDINATION & $63.8 \%$ & 5.1 & 8 & 5 & 19 \\
\hline PERCEPTION OF SUPERVISION & 54.3 & 10 & 11 & 5.8 & 20.7 \\
\hline
\end{tabular}


International Journal of Health, Medicine and Nursing Practice ISSN 2710-1150 (Online)

Vol. 3, Issue No. 3, pp 25- 43, 2021

www.carijournals.org

\section{Perception of respondents toward the MAKP nursing care model}
Components:
A DA
SA SD LA

Table 03: Regression analysis for perception of leadership and job satisfaction.

\section{Model Summary}

\begin{tabular}{|c|c|c|c|c|c|c|c|c|c|c|}
\hline \multirow[t]{2}{*}{ Model } & \multirow[t]{2}{*}{$\mathrm{R}$} & \multirow{2}{*}{$\begin{array}{c}\mathrm{R} \\
\text { Square }\end{array}$} & \multirow{2}{*}{$\begin{array}{c}\text { Adjusted } \\
\text { R } \\
\text { Square }\end{array}$} & \multirow{2}{*}{$\begin{array}{l}\text { Std. } \\
\text { Error of } \\
\text { the } \\
\text { Estimate }\end{array}$} & \multicolumn{6}{|c|}{ Change Statistics } \\
\hline & & & & & $\begin{array}{c}\text { R } \\
\text { Square } \\
\text { Change }\end{array}$ & $\begin{array}{c}\mathrm{F} \\
\text { Change }\end{array}$ & df1 & df2 & Sig.f change & Sig. F Change \\
\hline 1 & $.048^{\mathrm{a}}-\mathrm{c}$ & .002 & -.005 & .412 & .002 & .318 & & 136 & .574 & .574 \\
\hline
\end{tabular}

a. Predictors: (Constant), POL

Table 04: Coefficients a

\begin{tabular}{|c|c|c|c|c|c|c|}
\hline \multirow[t]{2}{*}{ Model } & \multicolumn{2}{|c|}{ Unstandardized Coefficients } & $\begin{array}{l}\text { Standardized } \\
\text { Coefficients }\end{array}$ & \multirow[t]{2}{*}{$\mathrm{t}$} & \multirow[t]{2}{*}{ Sig. } & $95.0 \%$ \\
\hline & $B$ & Std. Error & Beta & & & Lower Bound \\
\hline (Constant) & 1.348 & .146 & & 9.232 & .000 & 1.059 \\
\hline POL & .031 & .054 & .048 & .564 & .574 & -.077 \\
\hline
\end{tabular}

a. Dependent Variable: Job Satisfaction

Table 05: Model Summary

\begin{tabular}{|c|c|c|c|c|c|c|c|c|c|}
\hline \multirow[b]{2}{*}{ Model } & \multirow[b]{2}{*}{$\mathrm{R}$} & \multirow[b]{2}{*}{$\begin{array}{c}\mathrm{R} \\
\text { Square }\end{array}$} & \multirow{2}{*}{$\begin{array}{c}\text { Adjusted } \\
\text { R } \\
\text { Square }\end{array}$} & \multirow{2}{*}{$\begin{array}{c}\text { Std. } \\
\text { Error of } \\
\text { the } \\
\text { Estimate }\end{array}$} & \multicolumn{5}{|c|}{ Change Statistics } \\
\hline & & & & & $\begin{array}{c}\text { R } \\
\text { Square } \\
\text { Change }\end{array}$ & $\begin{array}{c}F \\
\text { Change }\end{array}$ & $\mathrm{df1}$ & df2 & $\begin{array}{l}\text { Sig. F } \\
\text { Change }\end{array}$ \\
\hline 1 & $.011^{a}$ & 0 & -0.007 & 0.412 & 0 & 0.018 & 1 & 136 & 0.894 \\
\hline
\end{tabular}


International Journal of Health, Medicine and Nursing Practice ISSN 2710-1150 (Online)

Vol. 3, Issue No. 3, pp 25- 43, 2021

www.carijournals.org

Table 06: Coefficients a

\begin{tabular}{|c|c|c|c|c|c|c|c|c|}
\hline \multirow{2}{*}{\multicolumn{2}{|c|}{ Model }} & \multicolumn{2}{|c|}{$\begin{array}{l}\text { Unstandardized } \\
\text { Coefficients }\end{array}$} & \multirow{2}{*}{$\begin{array}{c}\text { Standardized } \\
\text { Coefficients } \\
\text { Beta }\end{array}$} & \multirow{2}{*}{$\mathrm{t}$} & \multirow{2}{*}{ Sig. } & \multicolumn{2}{|c|}{$\begin{array}{l}95.0 \% \text { Confidence } \\
\text { Interval for B }\end{array}$} \\
\hline & & $B$ & Std. Error & & & & $\begin{array}{l}\text { Lower } \\
\text { Bound }\end{array}$ & $\begin{array}{l}\text { Upper } \\
\text { Bound }\end{array}$ \\
\hline \multirow{2}{*}{1} & (Constant) & 1.434 & 0.053 & & 27.172 & 0 & 1.329 & 1.538 \\
\hline & POC & -0.002 & 0.013 & -0.011 & -0.134 & 0.894 & -0.028 & 0.024 \\
\hline
\end{tabular}

a. Dependent Variable: Job_Satisfaction

As result of Simple Regression is displayed in (Table no.4). With beta value $.011(p=.000)$ showing significant positive relationship between communication and job satisfaction. Whereas value of adjusted $\mathrm{R}^{2}$ showing $-.007(\mathrm{~F}=.018, \mathrm{p}<.001)$ of variance caused by independent variable (communication) in dependent variable (job satisfaction). Hence, it is proved that there is a significant positive relationship between communication and job satisfaction.

Table 07: Model Summary

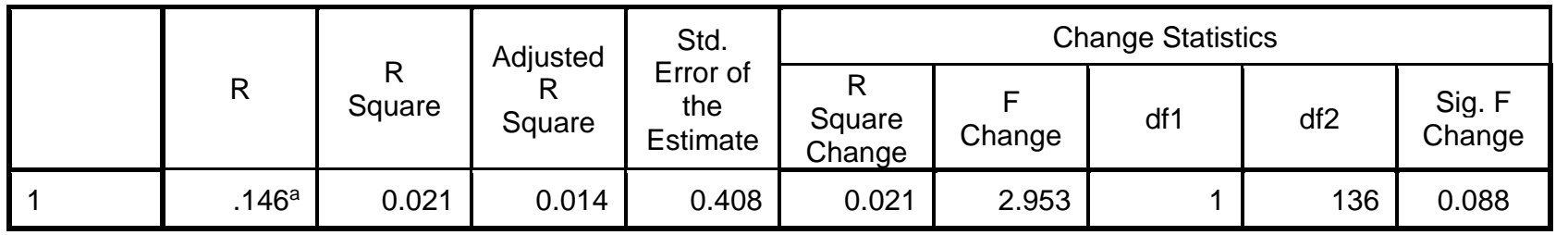

a. Predictors: (Constant), POCO

Table 08: Coefficients a

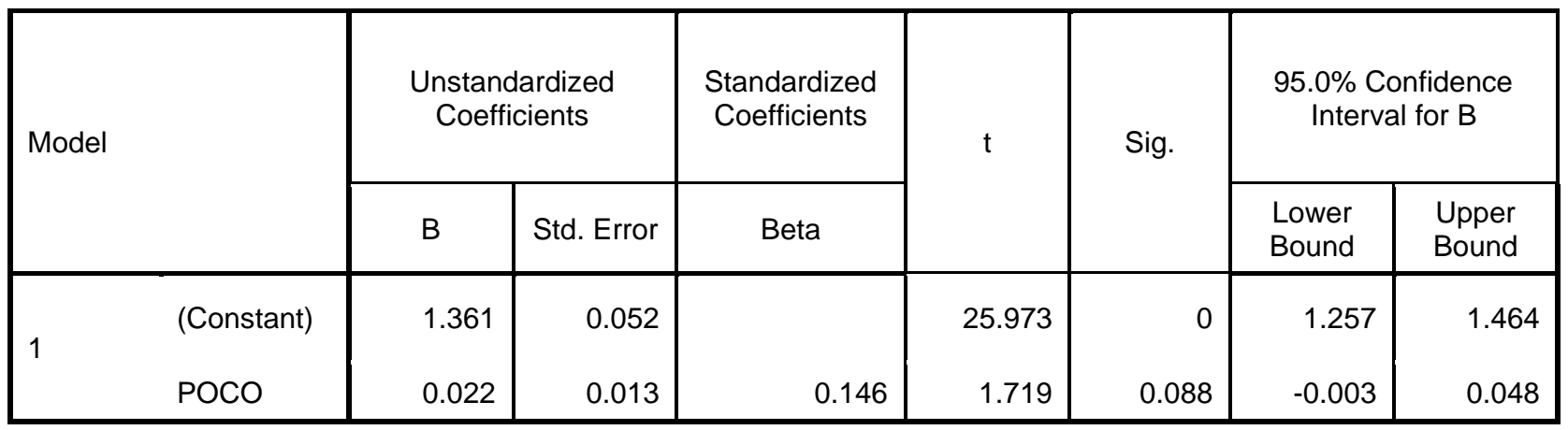

a. Dependent Variable: Job_Satisfaction 
International Journal of Health, Medicine and Nursing Practice ISSN 2710-1150 (Online)

Vol. 3, Issue No. 3, pp 25- 43, 2021

www.carijournals.org

As result of Simple Regression is displayed in (Table no.5). With beta value .146 ( $\mathrm{p}=.000)$ showing significant positive relationship between co-ordination and job satisfaction. Whereas value of adjusted $\mathrm{R}^{2}$ showing $-.014(\mathrm{~F}=.2 .95, \mathrm{p}<.001)$ of variance caused by independent variable (co-ordination) in dependent variable (job satisfaction). Hence, it is proved that there is a significant positive relationship between co-ordination and job satisfaction.

Table 09: Model Summary

\begin{tabular}{|c|c|c|c|c|c|c|c|c|c|}
\hline \multirow[b]{2}{*}{ Model } & \multirow[b]{2}{*}{$\mathrm{R}$} & \multirow[b]{2}{*}{$\begin{array}{c}\text { R } \\
\text { Square }\end{array}$} & \multirow{2}{*}{$\begin{array}{c}\text { Adjusted } \\
\text { R } \\
\text { Square }\end{array}$} & \multirow{2}{*}{$\begin{array}{l}\text { Std. } \\
\text { Error of } \\
\text { the } \\
\text { Estimate }\end{array}$} & \multicolumn{5}{|c|}{ Change Statistics } \\
\hline & & & & & $\begin{array}{c}\text { R } \\
\text { Square } \\
\text { Change } \\
\end{array}$ & $\begin{array}{c}F \\
\text { Change }\end{array}$ & $\mathrm{df1}$ & df2 & $\begin{array}{l}\text { Sig. F } \\
\text { Change }\end{array}$ \\
\hline 1 & $.079^{a}$ & 0.006 & -0.001 & 0.411 & 0.006 & 0.844 & 1 & 136 & 0.36 \\
\hline
\end{tabular}

a. Predictors: (Constant), POD

Table 10: Coefficients a

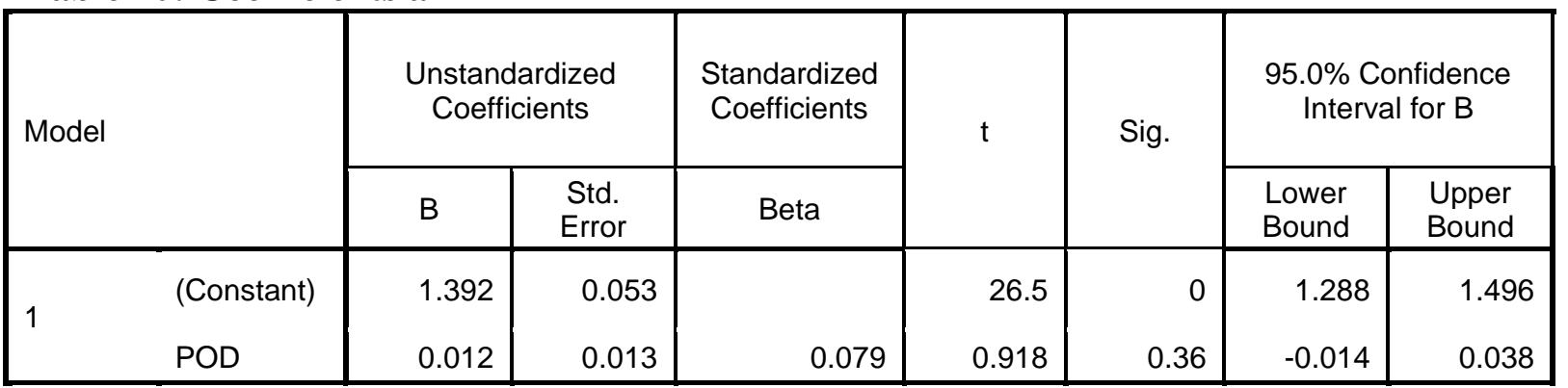

a. Dependent Variable: Job_Satisfaction

As result of Simple Regression is displayed in (Table no.6). With beta value $.079(p=.000)$ showing significant positive relationship between delegation and job satisfaction. Whereas value of adjusted $\mathrm{R}^{2}$ showing -.001 ( $\left.\mathrm{F}=.844, \mathrm{p}<.001\right)$ of variance caused by independent variable (delegation) in dependent variable (job satisfaction). Hence, it is proved that there is a significant positive relationship between delegation and job satisfaction.

Table 11: Model Summary 
International Journal of Culture and Religious Studies ISSN 2520-0815 (Online)

Vol. 5, Issue No.1, pp 25 - 33, 2021

WWW.carijournals.org

\begin{tabular}{|c|c|c|c|c|c|c|c|c|c|}
\hline \multirow[b]{2}{*}{ Model } & \multirow[b]{2}{*}{$\mathrm{R}$} & \multirow[b]{2}{*}{$\begin{array}{c}\text { R } \\
\text { Square }\end{array}$} & \multirow{2}{*}{$\begin{array}{c}\text { Adjusted } \\
\text { R } \\
\text { Square }\end{array}$} & \multirow{2}{*}{$\begin{array}{l}\text { Std. } \\
\text { Error of } \\
\text { the } \\
\text { Estimate }\end{array}$} & \multicolumn{5}{|c|}{ Change Statistics } \\
\hline & & & & & $\begin{array}{c}\mathrm{R} \\
\text { Square } \\
\text { Change }\end{array}$ & $\begin{array}{c}F \\
\text { Change }\end{array}$ & df1 & df2 & $\begin{array}{c}\text { Sig. F } \\
\text { Change }\end{array}$ \\
\hline 1 & $.216^{a}$ & 0.047 & 0.04 & 0.403 & 0.047 & 6.636 & 1 & 136 & 0.011 \\
\hline
\end{tabular}

a. Predictors: (Constant), POS

Table 12: Coefficients a

\begin{tabular}{|c|c|c|c|c|c|c|c|c|}
\hline \multicolumn{9}{|c|}{ Coefficients $^{a}$} \\
\hline \multirow{2}{*}{ Model } & & \multicolumn{2}{|c|}{$\begin{array}{l}\text { Unstandardized } \\
\text { Coefficients }\end{array}$} & \multirow{2}{*}{$\begin{array}{c}\begin{array}{c}\text { Standardized } \\
\text { Coefficients }\end{array} \\
\text { Beta }\end{array}$} & \multirow{2}{*}{$\mathrm{t}$} & \multirow{2}{*}{ Sig. } & \multicolumn{2}{|c|}{$\begin{array}{l}95.0 \% \text { Confidence } \\
\text { Interval for B }\end{array}$} \\
\hline & & B & Std. Error & & & & $\begin{array}{l}\text { Lower } \\
\text { Bound }\end{array}$ & $\begin{array}{l}\text { Upper } \\
\text { Bound }\end{array}$ \\
\hline \multirow{2}{*}{1} & (Constant) & 1.731 & 0.123 & & 14.128 & 0 & 1.489 & 1.974 \\
\hline & POS & -0.119 & 0.046 & -0.216 & -2.576 & 0.011 & -0.21 & -0.028 \\
\hline
\end{tabular}

a. Dependent Variable:Job_Satisfaction

As result of Simple Regression is displayed in (Table no.7). With beta value .216 ( $\mathrm{p}=.000$ ) showing significant positive relationship between supervision and job satisfaction. Whereas value of adjusted $\mathrm{R}^{2}$ showing $-.047(\mathrm{~F}=6.63, \mathrm{p}<.001)$ of variance caused by independent variable (supervision) in dependent variable (job satisfaction). Hence, it is proved that there is a significant positive relationship between supervision and job satisfaction

\section{DISCUSSION}

The MAKP model is relatively new to the hospitals of Lahore and Punjab. This is the first research to be published in Lahore because there is a lack of published research on the application of MAKP. The degree to which worker enjoy their work is referred to as a job satisfaction [13]. Owing to shifts in nursing sector, it is unable to attract sufficient number of people[14]. In this study few variables has a minor effect on job satisfaction including delegation and co-ordination. A study was conducted in west Cirebon shows that there is an effect of teamwork on job satisfaction [7]. Furthermore better management was found to increase work satisfaction in this report. This result matches of a study performed at Malang's Dr.saiful anwar hospital [8]. In this report satisfactory delegation was also shown to improve 
International Journal of Culture and Religious Studies ISSN 2520-0815 (Online)

Vol. 5, Issue No.1, pp 25 - 33, 2021

www.carijournals.org

job satisfaction among nurses. The proper instruction for doing a work is also a part of delegation. If there is proper task division and clear guidance then there will be more effective delegation and tend to increase job satisfaction[9]. The collected data shows that the delegation is more effective when done by experienced staff not by the primary nurse. There is no association of job satisfaction seen in the result with leadership. In this study the ratio of nursing staff who had positive view of leadership was very less due to the fact that the majority of chief nurses are diploma holder. According to a study conducted in Jakarta hospital, a highly educated person is more realistic, imaginative and open to challenges, and therefore more productive wen performing duties[10]. In this study the communication has no such effect on job satisfaction as compare to other elements of MAKP model [11]. Promotion, supervision, co-ordination and working condition all seemed to have an effect on job satisfaction [12].

\section{CONCLUSION}

The MAKP approach is regarded favorably by majority nurses. Employment satisfaction is linked to positive view of team work, management and delegation. The finding indicates that in order to boost the job satisfaction in other hospitals, team work, observation and delegation

\section{References}

1. Ahmed SM, Tolera M and Angamo MT (Assessment of job satisfaction among pharmacy professionals in south-west Ethiopia 2013). Int J Pharm Sci Res; 4(6):2351-8.

2. Al-Ahmadi HA, et al. (Job satisfaction of nurses in Ministry of Health Hospitals in Riyadh, Saudi Arabia. Saudi Medical Journal (2002); 23(6): 645- 50.

3. Andriani, ,et al( Nurses' job satisfaction in the application of the primary team method in the implementation of nursing care actions Management Application Journal.; . (2012) 10 (2): 419-424.

4. Andriani L. (The satisfaction of nurses in the aplication of primary team in the implementation of nursing care (A quantitative study at Dr. Saiful Anwar Hospital, Malang)). Jurnal Aplikasi Manajemen. 2012; 10(2): 419-424

5. Marquis BL, Huston CJ( Leadership roles and management function in nursing: therory and application 2012. )5th edition. Philadelphia: Lippincott Williams \& Wilkins.,

6. Marquis BL,,et al Leadership roles and management function in nursing therory and application. 5th edition. Philadelphia: Lippincott Williams \& Wilkins. .(2012)

7. Muadi. Hubungan iklim, .et al(The association of working atmosphere and job satisfaction with the productivity of nurses in inpatient ward Waled Hospital, Cirebon 2009). Universitas Indonesia,

8. Nursalam ,et al (Nursing management). Jakarta: Salemba Medika. (Nursing and care, the effects of the primary nursing care model). A systematic review. Journal of Nursing \& Care. 2014 
International Journal of Culture and Religious Studies

ISSN 2520-0815 (Online)

Vol. 5, Issue No.1, pp 25 - 33, 2021

9. Paramita GP, Rosa EM. ,. et al (The association of doctors-nurses collaboration and general practitioner's job satisfaction at Nganjuk Hospital(2014). Jurnal Medicoeticolegal dan Manajemen Rumah Sakit.

10. Paramita GP, Rosa,. et al (The association of doctors-nurses collaboration and general practitioner's job satisfaction at Nganjuk Hospital(2014). Jurnal Medicoeticolegal dan Manajemen Rumah Sakit.

11. Roelen, C.A., et al.,( Low job satisfaction does not identify nurses at risk of future sickness absenc) results from a Norwegian cohort study. Int. J. Nurs. Stud. (2013)50 (3), 366-373.

12. Rusmianingsih $\mathrm{N}$,.et al (The association between the implementation of team nursing care and nurses' work satisfaction in inpatient ward Tangerang District Hospital 2012). Universitas Indonesia,

13. Surianto, Sari NPP, ,et al ) (The association between chief of ward's leadership and working environment with nurses' job satisfaction in Catelia Paviliun Undata Hospital). Jurnal Kesehatan Tadulako.

14. Tim primer, .et al (The satisfaction of nurses in the aplication of primary team in the implementation of nursing care (A quantitative study at Dr. Saiful Anwar Hospital, Malang(2012). Jurnal Aplikasi Manajemen. 